\title{
EFFICIENCY EVALUATION OF THE IMPROVED TREATMENT AND PREVENTION COMPLEX IN PREGNANT WOMEN AFTER ASSISTED REPRODUCTIVE TECHNOLOGIES
}

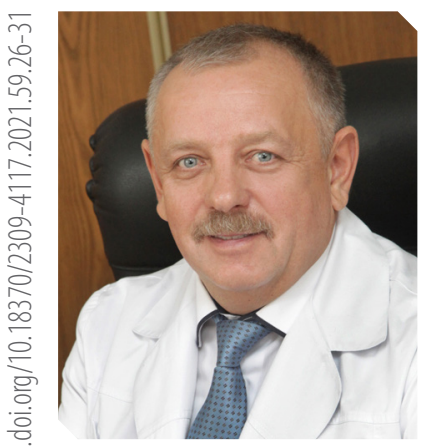

V.0. BENIUK

MD, professor, head of the Obstetrics and Gynecology Department No. 3, Bogomolets National Medical University, Kyiv ORCID: 0000-0002-5984-3307

L.M. VYGIVSKA

PhD, assistant professor, Obstetrics and Gynecology Department No. 3, Bogomolets NMU, Kyiv ORCID: 0000-0001-8939-2239

I.V. MAIDANNYK

PhD, assistant professor, Obstetrics and Gynecology Department No. 3, Bogomolets NMU, Kyiv ORCID: 0000-0003-0849-0406

T.V. KOVALIUK

PhD, assistant professor, Obstetrics and Gynecology Department No. 3, Bogomolets NMU, Kyiv ORCID: 0000-0001-9339-881X

0.0. CHORNA

PhD, assistant professor, Obstetrics and Gynecology Department No. 2, Bogomolets NMU, Kyiv ORCID: 0000-0002-9137-5056

S.V. BENIUK

PhD, assistant professor, Obstetrics and Gynecology Department No. 3, Bogomolets NMU, Kyiv ORCID: 0000-0003-4273-3934

I.A. USEVYCH

PhD, assistant professor, Obstetrics and Gynecology Department No. 3, Bogomolets NMU, Kyiv ORCID: 0000-0001-5200-8184

Contacts:

lgorV. Maidannyk

Bogomolets National Medical

University, Obstetrics and Gynecology

Department No. 3

V. Kuchera str. 7

03148, Kyiv, Ukraine

Tel.: +38 (096) 5040303

email: saman@yandex.ua

\section{INTRODUCTION}

Endocrine disorders preceding pregnancy can cause gestational complications in women whose pregnancy occurred after assisted reproductive technologies (ART) $[1,12,21]$. Development of hormonal disorders, especially in the early stages of gestation, can be the result of hyperandrogenism, luteal phase insufficiency, ovarian hyperstimulation, and further affect the course of pregnancy and fetoplacental complex $[3,8,13,20,23,24]$. Changes in the progesterone, estrogens, androgens, human chorionic gonadotropin $\beta$ ( $\beta$-hCG), and placental hormones value are most common $[6,10,15]$. The main role in regulating of normal physiological belongs to the chorion and trophoblast, which produce $\beta$-hCG, that is determines the level of steroid synthesis by the corpus luteum and contributes to the mother's adaptive responses to the gestational process $[11,12,15,22]$.

Study objective: to determine the role and effectiveness of the proposed therapeutic and preventive complex and psychoemotional correction of hormonal disorders in the pregnancy dynamics in pregnant women after ART to improve the antenatal observation and prevention of obstetric and perinatal complications.

\section{MATERIALS AND METHODS}

A prospective clinical examination of 299 pregnant women was performed:

- the main group included 249 women with a pregnancy after ART;

- the control group included 50 pregnant women with spontaneous pregnancy and its physiological course, who were registered in antenatal clinic in 6-8 weeks of gestation.

Main group is divided into subgroups depending on therapy and cause of infertility:

- subgroup I - pregnant women with tubalperitoneal type of infertility in anamnesis (subgroup IA - 49 women, subgroup IB - 45 women);

- subgroup II - pregnant women with endocrine type of infertility in anamnesis (subgroup IIA - 48 women, subgroup IIB - 39 women);

- subgroup III - pregnant women with a history of male infertility (subgroup IIIA - 36 women, subgroup III $B-32$ women).

Letter $A$ in a title of subgroup means that women received the proposed treatment, prevention and psychoemotional correction; letter B means that pregnant women were observed in accordance with generally standards of obstetric care regulated by orders of the Ministry of Health of Ukraine.

Pregnant women of the studied groups were representative by age, family and social status, and place of residence, which allowed us to further evaluation of the differences caused precisely by the etiological factors of infertility.

All women were examined in accordance with the orders of the Ministry of Health of Ukraine No. 417 "Methodological recommendations for outpatient obstetric and gynecological care" from 15.07.2011 [7], No. 787 "The procedure for using ART in Ukraine" from 09.09.2013 [6] and No. 579 "About approval of the procedure for sending women to infertility treatment using ART according to absolute indications for budget funds" from 29.11.04 [8].

The recommended complex of therapeutic and preventive measures for pregnant women after ART is:

1. Progesterone support (micronized progesterone orally and vaginally $200-400 \mathrm{mg}$ twice a day) up to 12 weeks, followed by adjustment of the dosage of progesterone drugs depending on the clinical picture of pregnancy.

2. Magnesium saturation (magnesium oxide light $342 \mathrm{mg}$ and magnesium carbonate light 670 $\mathrm{mg}$, which corresponds to magnesium ions 365 $\mathrm{mg}$, one effervescent tablet once a day during pregnancy).

3. Folic acid $200 \mu \mathrm{g}$ of folic acid and metafolin $200 \mu \mathrm{g}, 1$ tablet 1 time a day orally with meals before pregnancy and during the first 16 weeks of pregnancy.

4. L-arginine aspartate in a solution for oral use 5 $\mathrm{ml}(1 \mathrm{ml}$ of the solution contains L-arginine aspartate $200 \mathrm{mg}) 3$ times a day from the 8th week to the 16th week of pregnancy $[5,14]$.

5. $\omega-3$ polyunsaturated fatty acids 1 capsule three times a day starting from the 12th week of pregnancy.

6. Long term psychological correction on the eve of the ART program, at 8-10 weeks, 16-18 weeks and 28-30 weeks of pregnancy $[2,25]$.

Psychocorrection classes were conducted in a closed homogeneous group (from 7 to 12 participants) with a frequency of 3 times a week for 1.5 hours for 2-3 weeks. Psychocorrection was based mainly on the method of catatime-imaginative ex- 
perience of images, as well as elements of body-oriented methods and autogenic training. Negative triggers were identified and destroyed, which improves the psychological and somatic state. In addition, the work in the group was aimed at harmonizing the individual, merging it with people around them, getting out of the narrow egocentric world, and engaging in transpersonal experiences $[4,19]$.

Descriptive and variational statistics using the Student's criterion and the Fischer angular transformation method were using. Obtained results were calculated with using Statistica for Windows and Microsoft Excel 2016 programs. Discrepancies were determined as possible at $p<0.05$.

\section{RESULTS}

We drew attention to a significant increase in $\beta$-hCG in women of the studied groups in the first trimester against the background of proposed treatment. Special attention was paid to the $\beta$-hCG level at 5-6 and 7-8 weeks of pregnancy (gestational age of the onset of placental formation).

The average values of $\beta$-hCG in the IA subgroup against the background of proposed treatment and psychoemotional correction were as close as possible to the indicators in the control group and the physiological norm. The average $\beta$-HCG value at 3-4 weeks of gestation in the IA subgroup $(121.3 \pm 5.8 \mathrm{mIU} /$ $\mathrm{mL})$ was $33 \%$ higher than in the IB subgroup $(91.2 \pm 6.4 \mathrm{mIU} /$ $\mathrm{mL})(\mathrm{p}<0.05)$. A similar trend persisted at 5-6 weeks. The average $\beta$-HCG value in the IA subgroup was $31 \%$ higher than in the IB subgroup $(194.8 \pm 8.1 \mathrm{mIU} / \mathrm{mL}$ and $147.6 \pm 9.2 \mathrm{mIU} / \mathrm{mL}$, respectively) $(p<0.05)$. At $7-8$ weeks the average $\beta$-hCG value in subgroup IA was $37 \%$ higher than in the subgroup IB $(222.5 \pm 9.4$ $\mathrm{mIU} / \mathrm{mL}$ and $162.2 \pm 8.7 \mathrm{mIU} / \mathrm{mL}$, respectively) $(p<0.05)$.

A significant $\beta$-hCG increase in the dynamics of treatment was also noted in women with a history of endocrine infertility. The average $\beta$-HCG value at $3-4$ weeks of gestation in subgroup IIA $(131.8 \pm 6.3 \mathrm{mIU} / \mathrm{mL})$ was $32 \%$ higher than in the IIB subgroup $(99.4 \pm 8.3 \mathrm{mIU} / \mathrm{mL})(p<0.05)$. The average $\beta-\mathrm{HCG}$ value at $5-6$ weeks of gestation in the subgroup IIA significantly increased by $31 \%(199.1 \pm 8.7 \mathrm{mlU} / \mathrm{mL})$ than in the IIB subgroup $(151.4 \pm 11.3$ $\mathrm{mIU} / \mathrm{mL})(\mathrm{p}<0.05)$.

The average $\beta$-HCG value at 7- 8 weeks of gestation in the subgroup IIA was 33\% higher than in the IIB subgroup (226.4 \pm 8.2 $\mathrm{mIU} / \mathrm{mL}$ and $169.3 \pm 7.9 \mathrm{mIU} / \mathrm{mL}$, respectively) $(p<0.05)$.

The average $\beta$-HCG value in the subgroups IIIA and IIIB did not have a significant difference in the dynamics of the first trimester compared to the control group ( $p>0.05$ ).

Thinking about persistent progesterone deficiency in women with pregnancy as a result of ART cycles, which was confirmed by our studies, all women received progesterone support in accordance with the recommendations for management after ART. At the same time, we drew attention to a significantly higher increase in progesterone levels in women of subgroup IA, IIA and IIIA against the background of the proposed treatment. The role of psychoemotional correction in the progesterone regulation in women after ART is due to the inverse correlation between the levels of stress-implementing, gonadotropic and sex steroids, in particular in the prolactin/progesterone ratio, because pregnancy, which occurs against the background of chronic stress, and increased pro- lactin levels as a result, is characterized by progressive yellow body insufficiency with low secretory activity, that is lead to a significant progesterone decrease and progesterone-associated pregnancy complications.

The average values of progesterone levels in the IA subgroup significantly exceeded similar indicators in the IB subgroup against the background of the proposed treatment and psychoemotional correction. Starting from 3-4 weeks of pregnancy the average progesterone level in the subgroup IA was 49\% higher than in the IB subgroup $(131.9 \pm 4.1 \mathrm{nmol} / \mathrm{L}$ and $88.4 \pm 6.5$ $\mathrm{nmol} / \mathrm{L}$, respectively; $\mathrm{p}<0.05$ ). Progesterone value in the period of placental formation (critical pregnancy period) in pregnant women who received the proposed complex (subgroup IA) significantly increased by $47 \%$ compared to the IB subgroup (164.4 $\pm 5.4 \mathrm{nmol} / \mathrm{L}$ and $111.2 \pm 8.4 \mathrm{nmol} / \mathrm{L}$, respectively; $\mathrm{p}<0.05)$. The average progesterone value at 7-8 weeks of pregnancy in the subgroup IA increased by $38 \%$ compared to women who received a generally treatment (subgroup IA $-193.9 \pm 8.6 \mathrm{nmol} / \mathrm{L}$; subgroup IB $-139.8 \pm 10.3 \mathrm{nmol} / \mathrm{L} ; \mathrm{p}<0.05)$. A significant progesterone increase in the subgroup IA led to a significant decrease in the frequency of threatened miscarriage by $41.6 \%$ (I group before treatment - 66 (70.2\%), subgroup I - $14(28.6 \%), p<0.05$ and spontaneous miscarriages among in group I (subgroup IA $14(28.6 \%)$, and subgroup IB - $26(57.7 \%), p<0.05$.

The average progesterone values in subgroup IIA significantly exceeded similar indicators in the subgroup IIB against the background of the proposed treatment and psychoemotional correction. The average progesterone level at 3-4 weeks of pregnancy in the subgroup IIA was $95 \%$ higher than in the subgroup IIB $(148.4 \pm 6.2 \mathrm{nmol} / \mathrm{L}$ and subgroup $76.1 \pm 4.3 \mathrm{nmol} / \mathrm{L}$, respectively; $p<0.05$ ). The average progesterone level at 5-6 weeks of pregnancy in the subgroup IIA was $80 \%$ higher than in the subgroup IIB $(169.8 \pm 7.6 \mathrm{nmol} / \mathrm{L}, 94.3 \pm 5.9 \mathrm{nmol} / \mathrm{L}$, respectively; $\mathrm{P}$ $<0.05)$. The average progesterone level at 7-8 weeks of pregnancy in the subgroup IIA was $73 \%$ higher than in the subgroup IIB $(204.2 \pm 10.8 \mathrm{nmol} / \mathrm{L}, 117.6 \pm 8.7 \mathrm{nmol} / \mathrm{L}$, respectively, $\mathrm{p}<0.05)$. A significant progesterone increase in women with a history of endocrine infertility led to a significant decrease in the frequency of threatened miscarriage by $37.1 \%$ (group II before treatment $54(62.1 \%)$, subgroup IIA $-12(25.0 \%)$ ? $p<0.05$, and by $20 \%$ of the hemorrhagic syndrome frequency in pregnant women in the first trimester (before treatment - 20 (37.1\%), subgroup IIA $4(8.3 \%), p<0.05$.

There was no significant difference in progesterone levels in women of subgroup IIIA and IIIB in the dynamics of the first trimester.

Proposed treatment complex in combination with psychoemotional correction in the subgroup IA, IIA and IIIA led to the establishment of estradiol levels within the physiological norm in the dynamics of the first trimester of pregnancy, which synergistically affected the progesterone/estradiol ratio (Table 1).

Special attention was paid to the level of stress hormones (cortisol and prolactin) against the background of the proposed treatment and psychoemotional correction in the first trimester of pregnancy. Repeated determination of cortisol and prolactin levels was performed 2 weeks after the start of the proposed psychoemotional correction for pregnant women in the IA, IIA, and IIIA subgroups (Table 2). 
Table 1. Average estradiol level and progesterone/estradiol ratio in the blood of pregnant women after ART in the dynamics of treatment

\begin{tabular}{|c|c|c|c|c|c|c|c|}
\hline \multirow{3}{*}{$\begin{array}{l}\text { Term of } \\
\text { pregnancy } \\
\text { (weeks) }\end{array}$} & \multicolumn{6}{|c|}{ Main group $(n=249)$} & \multirow{3}{*}{$\begin{array}{c}\text { Control } \\
\text { group } \\
(n=50)\end{array}$} \\
\hline & \multicolumn{2}{|c|}{ I group $(n=94)$} & \multicolumn{2}{|c|}{ II group $(\mathrm{n}=87$ ) } & \multicolumn{2}{|c|}{ III group $(n=68)$} & \\
\hline & Subgroup IA $(n=49)$ & Subgroup IB $(n=45)$ & Subgroup $\| A(n=48)$ & Subgroup IIB $(n=39)$ & Subgroup IIIA $(n=36)$ & Subgroup IIIB $(n=32)$ & \\
\hline \multicolumn{8}{|c|}{ Average estradiol level, $\mathrm{nmol} / \mathrm{l}(\mathrm{M} \pm \mathrm{m})$} \\
\hline $3-4$ & $5.1 \pm 0.23^{* *}$ & $9.3 \pm 0.47^{*}$ & $5.3 \pm 0.31^{* *}$ & $10.8 \pm 0.55^{*}$ & $5.4 \pm 0.29$ & $9.7 \pm 0.61^{*}$ & $5.4 \pm 0.33$ \\
\hline $5-6$ & $6.2 \pm 0.44^{* *}$ & $9.0 \pm 0.31^{*}$ & $6.4 \pm 0.48^{* *}$ & $10.1 \pm 0.34^{*}$ & $6.1 \pm 0.41$ & $9.4 \pm 0.58^{*}$ & $6.5 \pm 0.41$ \\
\hline $7-8$ & $7.6 \pm 0.41$ & $8.4 \pm 0.61$ & $8.0 \pm 0.39$ & $9.1 \pm 0.27^{*}$ & $7.8 \pm 0.40$ & $8.6 \pm 0.34$ & $7.3 \pm 0.56$ \\
\hline \multicolumn{8}{|c|}{ Progesterone/estradiol ratio $(\mathrm{M} \pm \mathrm{m})$} \\
\hline $3-4$ & $18.2 \pm 3.1^{* *}$ & $10.9 \pm 2.1^{*}$ & $19.6 \pm 2.7^{* *}$ & $9.5 \pm 1.8^{*}$ & $19.0 \pm 3.1$ & $17.4 \pm 3.2$ & $20.4 \pm 2.3$ \\
\hline $5-6$ & $21.8 \pm 2.6^{* *}$ & $13.6 \pm 1.3^{*}$ & $22.3 \pm 3.3^{* *}$ & $12.1 \pm 2.3^{*}$ & $21.3 \pm 2.6$ & $19.1 \pm 2.5$ & $22.1 \pm 2.4$ \\
\hline $7-8$ & $20.4 \pm 3.0$ & $14.4 \pm 2.6^{*}$ & $20.8 \pm 2.6^{* *}$ & $13.9 \pm 2.2^{*}$ & $22.9 \pm 3.4$ & $18.6 \pm 2.3$ & $21.6 \pm 2.7$ \\
\hline
\end{tabular}

${ }^{*}$ statistically significant differences compared to the control group ( $p<0.05$ );

** statistically significant differences between $A$ and B subgroups

The average cortisol value in women of subgroup IA and IIA against the background of the proposed therapy in the first trimester of pregnancy was significantly $50 \%$ lower compared in the subgroup IB and IIB. Also, it was possible to significantly reduce cortisol levels in pregnant women with a history of male infertility factor. In subgroup IA, IIA and IIIA it was possible to bring cortisol indicators as close as possible to the physiological norm and to the indicators in the control group.

The average prolactin value in the IA subgroup against the background of the proposed therapy in the first trimester of pregnancy was significantly lower compared to the IB subgroup (Table 2).

A significant decrease in average prolactin levels was also observed in women of subgroup IIA and IIIA compared to the subgroup IIB and IIIB, respectively.

Thus, the positive effect of the proposed treatment and psychoemotional correction in the first trimester of pregnancy in women of subgroup IA, IIA and IIIA is confirmed by a significant increase in the average $\beta$-hCG level, especially in term of gesta- tion, which correspond to the placenta formation, a significant increase in the average progesterone level, a significant decrease in the average estradiol and estrogen/progesterone ratio. This is reflected in a significant decrease of the progesterone-associated complications in the first trimester of pregnancy.

Significant decrease in the average cortisol and prolactin levels against the background of psychoemotional correction led to a balance of the central nervous system processes, which is reflected in the normalization of personal anxiety, reactive anxiety and is confirmed by the "attitude to pregnancy" test.

Special attention in our study was paid to the concentration of placental hormones (estradiol and progesterone) and stress hormones - pituitary (prolactin) and adrenal glands (cortisol), which most affect the pregnancy in the second and third trimesters.

Average estradiol index (Table 3 ) in the study groups in the second trimester (subgroup IA - $32.4 \pm 2.6 \mathrm{nmol} / \mathrm{L}$, subgroup IIA - $31.6 \pm 2.1 \mathrm{nmol} / \mathrm{L}$; subgroup IB $-32.1 \pm 2.2 \mathrm{nmol} / \mathrm{L}$, subgroup IIB $-34.3 \pm 1.8 \mathrm{nmol} / \mathrm{L}$; subgroup IIIA $-33.8 \pm 2.7 \mathrm{nmol} / \mathrm{L}$, subgroup IIIB $-32.5 \pm 2.8$, control group $-28.1 \pm 3.4 \mathrm{nmol} / \mathrm{L}$;

Table 2. Average cortisol and prolactin levels in the blood of pregnant women after ART in the dynamics of treatment, $\mathrm{ng} / \mathrm{ml}(\mathrm{M} \pm \mathrm{m})$

\begin{tabular}{|c|c|c|c|c|c|c|c|}
\hline \multirow{3}{*}{$\begin{array}{l}\text { Term of } \\
\text { pregnancy } \\
\text { (weeks) }\end{array}$} & \multicolumn{6}{|c|}{ Main group $(n=249)$} & \multirow{3}{*}{$\begin{array}{c}\text { Control } \\
\text { group } \\
(n=50)\end{array}$} \\
\hline & \multicolumn{2}{|c|}{ I group $(n=94)$} & \multicolumn{2}{|c|}{ II group $(\mathrm{n}=87)$} & \multicolumn{2}{|c|}{ III group $(n=68)$} & \\
\hline & Subgroup IA $(n=49)$ & Subgroup IB $(n=45)$ & Subgroup $\| A(n=48)$ & Subgroup IIB $(n=39)$ & Subgroup IIIA $(n=36)$ & Subgroup IIIB $(n=32)$ & \\
\hline \multicolumn{8}{|c|}{ Average cortisol level } \\
\hline $5-6$ & $101.4 \pm 9.2^{* *}$ & $203.5 \pm 13.7^{*}$ & $111.5 \pm 8.4^{* *}$ & $200.4 \pm 13.6^{*}$ & $116.2 \pm 8.3^{* *}$ & $193.7 \pm 12.1^{*}$ & $143.1 \pm 11.7$ \\
\hline $7-8$ & $122.3 \pm 7.6^{* *}$ & $219.4 \pm 12.9^{*}$ & $134.9 \pm 9.3^{* *}$ & $223.0 \pm 14.7^{*}$ & $129.9 \pm 7.3^{* *}$ & $208.2 \pm 13.1^{*}$ & $161.2 \pm 12.1$ \\
\hline $9-10$ & $148.3 \pm 11.2^{* *}$ & $231.4 \pm 11.2^{*}$ & $153.2 \pm 7.9^{* *}$ & $246.8 \pm 13.4^{*}$ & $150.1 \pm 8.9^{* *}$ & $228.3 \pm 11.4^{*}$ & $185.7 \pm 11.9$ \\
\hline $11-12$ & $169.2 \pm 10.3^{* *}$ & $251.1 \pm 13.4^{*}$ & $172.5 \pm 8.2^{* *}$ & $261.7 \pm 12.6^{*}$ & $164.4 \pm 9.4^{* *}$ & $246.4 \pm 12.3^{*}$ & $192.9 \pm 14.7$ \\
\hline \multicolumn{8}{|c|}{ Average prolactin level } \\
\hline $5-6$ & $69.4 \pm 5.1^{* *}$ & $147.2 \pm 8.4^{*}$ & $74.7 \pm 6.0^{* *}$ & $143.4 \pm 6.2^{*}$ & $73.5 \pm 4.6^{* *}$ & $138.2 \pm 5.3^{*}$ & $71.8 \pm 5.2$ \\
\hline $7-8$ & $89.5 \pm 7.3^{* *}$ & $166.3 \pm 6.9^{*}$ & $85.8 \pm 7.6^{* *}$ & $169.5 \pm 6.7^{*}$ & $86.4 \pm 6.5^{* *}$ & $161.7 \pm 8.7^{*}$ & $84.3 \pm 6.9$ \\
\hline $9-10$ & $99.1 \pm 8.6^{* *}$ & $181.1 \pm 7.9^{*}$ & $94.6 \pm 9.1^{* *}$ & $189.1 \pm 7.2^{*}$ & $92.1 \pm 7.8^{* *}$ & $184.7 \pm 9.1^{*}$ & $93.5 \pm 7.1$ \\
\hline $11-12$ & $102.3 \pm 8.9^{* *}$ & $197.4 \pm 8.1^{*}$ & $101.4 \pm 7.6^{* *}$ & $194.3 \pm 7.6^{*}$ & $99.3 \pm 7.2^{* *}$ & $200.4 \pm 7.3^{*}$ & $99.7 \pm 6.4$ \\
\hline
\end{tabular}

* statistically significant differences compared to the control group $(p<0.05)$;

** statistically significant differences between subgroups $A$ and $B$ 
$\mathrm{p}>0.05$ ) and the third (subgroup IA $-50.4 \pm 3.2 \mathrm{nmol} / \mathrm{L}$, subgroup IIA - $51.5 \pm 2.6 \mathrm{nmol} / \mathrm{L}$; subgroup IB $-52.7 \pm 4.1 \mathrm{nmo-}$ $\mathrm{I} / \mathrm{L}$, subgroup IIB $-49.2 \pm 2.3 \mathrm{nmol} / \mathrm{L}$; subgroup IIIA $-51.8 \pm 3.2$ $\mathrm{nmol} / \mathrm{L}$, subgroup IIIB $-52.1 \pm 3.1 \mathrm{nmol} / \mathrm{L}$, control group -44.3 $\pm 2.6 \mathrm{nmol} / \mathrm{L} ; \mathrm{p}>0.05$ ) trimester was within the physiologically acceptable norm and did not have significant differences in comparison with the value of the average indicator of pregnant women in the control group.

Micronized progesterone in combination with folic acid, $\omega-3$ polyunsaturated fatty acids, magnesium saturation and L-arginine aspartate, and psychoemotional correction already after 14 days of treatment contributed to a significant progesterone increase in the blood serum in the subgroup IA, IIA and IIIA in comparison with pregnant women who received generally treatment and with the control group (Table 3).

In pregnant women of the IA subgroup who received the proposed treatment complex and psychoemotional correction complex, the average progesterone value at 23-24 weeks of pregnancy was $358.3 \pm 10.9 \mathrm{nmol} / \mathrm{L}$, which is $45 \%$ more compared to the average in the IB subgroup $-245.8 \pm 11.6 \mathrm{nmol} / \mathrm{L}$ ( $p$ $<0.05$ ). The average value of progesterone in pregnant women with a history of endocrine infertility against the background of the proposed treatment complex was $378.5 \pm 11.2 \mathrm{nmol} / \mathrm{L}$, which is $32 \%$ more than in the IIB subgroup $-286.1 \pm 10.3 \mathrm{nmol} / \mathrm{L}$ ( $p$ $<0.05$ ). At the same time, in women with a history of male infertility factor, the average value of progesterone against the background of the proposed complex was $369.7 \pm 10.1 \mathrm{nmol} / \mathrm{L}$, which is $27 \%$ more compared to the average in the IIIB subgroup $289.3 \pm 10.6 \mathrm{nmol} / \mathrm{L}(\mathrm{p}<0.05)$.

Studying the average values of progesterone in the dynamics of pregnancy at 33-34 weeks, we drew attention to the stable concentration of this hormone in the blood serum of pregnant women of the studied groups. In pregnant women of the IA subgroup, the average progesterone value was $681.6 \pm 11.4 \mathrm{nmol} / \mathrm{L}$, which is $35 \%$ more than the average in the IB subgroup - 501.7 $\pm 10.2 \mathrm{nmol} / \mathrm{L}(\mathrm{p}<0.05)$. The average value of progesterone in pregnant women with a history of endocrine infertility against the background of the proposed treatment complex was $694.3 \pm$ $12.5 \mathrm{nmol} / \mathrm{L}$, which is $45 \%$ more than in the IIB subgroup -478.6 $\pm 10.1 \mathrm{nmol} / \mathrm{L}(\mathrm{p}<0.05)$.

At the same time, the average progesterone value against the background of the proposed complex in women with a history of male infertility factor was $678.2 \pm 12.3 \mathrm{nmol} / \mathrm{L}$, which is $25 \%$ more compared to the average value in the IIIB subgroup - 538.7 $\pm 11.2 \mathrm{nmol} / \mathrm{L}(\mathrm{p}<0.05)$.

A progesterone increase in the studied groups occurred within the gestational norm, but there was more significant progesterone increase in pregnant women who received the proposed treatment complex, reaching the upper limit of the physiological norm. The positive effect of the proposed therapy contributed to a significant reduction in the threatening late spontaneous miscarriages in the group I (subgroup IA - 8 (16.3\%), subgroup IB $-13(28.9 \%), p<0.05)$, a decrease in the number of threatening premature birth by $24.0 \%$ (before treatment - 34 (36.2\%), subgroup IA - $6(12.2 \%), p<0.05)$. There was also a significant decrease in the number of threatened preterm birth between subgroup IA and IB (subgroup IA - 6 (12.2\%), subgroup IB - 15 $(33.3 \%), p<0.05)$ and placenta-associated complications during pregnancy in the second and third trimesters.

Taking into account the psychoemotional aspects of pregnancy complications, which are characterized by miscarriage, prematurity and chronic stress that accompanies pregnancy after ART, and causes of stress-associated hormones hypersecretion by the pituitary gland and adrenal glands, we believe that restoration of physiological gestational cortisol and prolactin levels can be considered as a marker of the therapy effectiveness and psychoemotional correction aimed at prolonging pregnancy.

We drew attention to a significant cortisol and prolactin decrease in the subgroup IA, IIA and IIIA at 23-24 and 33-34 weeks of pregnancy against the background of the proposed therapy and psychoemotional correction (Table 4).

Thus, the average cortisol value at 23-24 weeks of pregnancy in the subgroup IA decreased by $42 \%$ to $162.1 \pm 8.9 \mathrm{ng} / \mathrm{mL}$ (subgroup IB $-231.7 \pm 9.1 \mathrm{ng} / \mathrm{mL}, \mathrm{p}<0.05$ ). The average cortisol value in pregnant women with a history of endocrine infertility against the background of the proposed treatment was $154.4 \pm$ $8.7 \mathrm{ng} / \mathrm{mL}$, which is $62 \%$ less than in the IIB subgroup $-251.6 \pm$ $9.3 \mathrm{ng} / \mathrm{mL}(\mathrm{p}<0.05)$. At the same time, the average cortisol value against the background of the proposed complex in women with a history of male infertility factor was $146.3 \pm 10.2 \mathrm{ng} / \mathrm{mL}$, which is $63 \%$ less compared to the IIIB subgroup $-238.5 \pm 8.5 \mathrm{ng} /$ $\mathrm{mL}(\mathrm{p}<0.05)$. The average cortisol values in the subgroups IA, IIA, and IIIA approached the indicator in the control group and the physiological norm and had no significant differences ( $p>0.05)$.

Table 3. Estradiol and progesterone levels in the blood of pregnant women after ART at $23-24$ and 33-34 weeks of pregnancy, nmol/L

\begin{tabular}{|c|c|c|c|c|c|c|c|}
\hline \multirow{3}{*}{$\begin{array}{l}\text { Term of } \\
\text { pregnancy } \\
\text { (weeks) }\end{array}$} & \multicolumn{6}{|c|}{ Main group $(n=249)$} & \multirow{3}{*}{$\begin{array}{l}\text { Control } \\
\text { group } \\
(n=50)\end{array}$} \\
\hline & \multicolumn{2}{|c|}{ I group $(\mathrm{n}=94)$} & \multicolumn{2}{|c|}{ II group $(n=87)$} & \multicolumn{2}{|c|}{ III group $(n=68)$} & \\
\hline & Subgroup IA $(n=49)$ & Subgroup IB $(n=45)$ & Subgroup IIA $(n=48)$ & Subgroup IIB $(n=39)$ & Subgroup IIIA $(n=36)$ & Subgroup IIIB $(n=32)$ & \\
\hline \multicolumn{8}{|c|}{ 23-24 weeks of pregnancy } \\
\hline Estradiol & $32.4 \pm 2.6$ & $31.6 \pm 2.1$ & $32.1 \pm 2.2$ & $34.3 \pm 1.8$ & $33.8 \pm 2.7$ & $32.5 \pm 2.8$ & $28.1 \pm 3.4$ \\
\hline Progesterone & $358.3 \pm 10.9^{* *}$ & $245.8 \pm 11.6^{*}$ & $378.5 \pm 11.2^{* *}$ & $286.1 \pm 10.3^{*}$ & $369.7 \pm 10.1^{* *}$ & $289.3 \pm 10.6^{*}$ & $341.2 \pm 6.9$ \\
\hline \multicolumn{8}{|c|}{ 33-34 weeks of pregnancy } \\
\hline Estradiol & $50.4 \pm 3.2^{* *}$ & $51.5 \pm 2.6$ & $52.7 \pm 4.1^{* *}$ & $49.2 \pm 2.3$ & $51.8 \pm 3.2^{* *}$ & $52.1 \pm 3.1$ & $44.3 \pm 2.6$ \\
\hline Progesterone & $681.6 \pm 11.4^{* *}$ & $501.7 \pm 10.2^{*}$ & $694.3 \pm 12.5^{* *}$ & $478.6 \pm 10.1^{*}$ & $678.2 \pm 12.3^{* *}$ & $538.7 \pm 11.2^{*}$ & $633.4 \pm 5.8$ \\
\hline
\end{tabular}

* statistically significant differences compared to the control group $(p<0.05)$;

${ }^{* *}$ statistically significant differences between subgroups $A$ and $B$ 
Table 4. Cortisol and prolactin levels in the blood of pregnant women after ART at 23-24 and 33-34 weeks of pregnancy, $\mathrm{ng} / \mathrm{mL}(\mathrm{M} \pm \mathrm{m})$

\begin{tabular}{|c|c|c|c|c|c|c|c|}
\hline \multirow{3}{*}{$\begin{array}{l}\text { Term of } \\
\text { pregnancy } \\
\text { (weeks) }\end{array}$} & \multicolumn{6}{|c|}{ Main group $(n=249$ ) } & \multirow{3}{*}{$\begin{array}{l}\text { Control } \\
\text { group } \\
(\mathrm{n}=50)\end{array}$} \\
\hline & \multicolumn{2}{|c|}{ I group $(n=94)$} & \multicolumn{2}{|c|}{ II group $(\mathrm{n}=87)$} & \multicolumn{2}{|c|}{ III group $(n=68)$} & \\
\hline & Subgroup IA $(n=49)$ & Subgroup IB $(n=45)$ & Subgroup IIA $(\mathrm{n}=48)$ & Subgroup III $(n=39)$ & Subgroup IIIA $(n=36)$ & Subgroup IIIB $(n=32)$ & \\
\hline \multicolumn{8}{|c|}{ 23-24 weeks of pregnancy } \\
\hline Cortisol & $162.1 \pm 8.9^{* *}$ & $231.7 \pm 9.1^{*}$ & $154.4 \pm 8.7^{* *}$ & $251.6 \pm 9.3^{*}$ & $146.3 \pm 10.2^{* *}$ & $238.5 \pm 8.5^{*}$ & $171.9 \pm 8.2$ \\
\hline Prolactin & $124.3 \pm 7.1^{* *}$ & $262.4 \pm 8.9^{*}$ & $119.7 \pm 8.1^{* *}$ & $271.6 \pm 7.6^{*}$ & $127.6 \pm 8.4^{* *}$ & $259.2 \pm 9.1^{*}$ & $121.7 \pm 6.1$ \\
\hline \multicolumn{8}{|c|}{ 33-34 weeks of pregnancy } \\
\hline Cortisol & $209.6 \pm 9.3^{* *}$ & $308.2 \pm 9.7^{*}$ & $213.5 \pm 8.9^{* *}$ & $316.4 \pm 9.1^{*}$ & $201.3 \pm 8.7^{* *}$ & $281.7 \pm 11.4^{*}$ & $228.6 \pm 9.4$ \\
\hline Prolactin & $154.3 \pm 8.2^{* *}$ & $297.7 \pm 10.4^{*}$ & $167.9 \pm 9.5^{* *}$ & $287.3 \pm 9.5^{*}$ & $159.5 \pm 10.1^{* *}$ & $277.3 \pm 9.1^{*}$ & $175.9 \pm 7.6$ \\
\hline
\end{tabular}

Further cortisol study at 33-34 weeks of pregnancy in the main group noted significant differences in the indicators of women who received the proposed treatment and psychoemotional correction compared to pregnant women who were observed according to generally accepted norms.

The average cortisol value at 33-34 weeks of pregnancy in the IA subgroup increased in accordance with the physiological norm $(209.6 \pm 9.3 \mathrm{ng} / \mathrm{mL})$, which is $47 \%$ less compared to the IB subgroup - $308.2 \pm 9.7 \mathrm{ng} / \mathrm{mL}(\mathrm{p}<0.05)$. The average cortisol value in the subgroup IIA was $213.5 \pm 8.9 \mathrm{ng} / \mathrm{mL}$, which is $48 \%$ less than in the subgroup IIB $-316.4 \pm 9.1 \mathrm{ng} / \mathrm{mL}(p<0.05)$. At the same time, the average cortisol value in the subgroup IIIB was $201.3 \pm 8.7 \mathrm{ng} / \mathrm{mL}$, which is $39 \%$ less compared to the subgroup IIIB - $281.7 \pm 11.4 \mathrm{ng} / \mathrm{mL}(\mathrm{p}<0.05)$.

The average cortisol values in the subgroups IA, IIA, and IIIA approached the indicator in the control group and the physiological norm and had no significant differences $(p>0.05)$.

Similar trends continued with prolactin level. In pregnant women who received conventional treatment we noted a rather slow decrease of this hormone.

Rapid normalization of prolactin indicators in pregnant women who received the proposed treatment and psychoemotional correction is inherent. Already at 23-24 weeks of pregnancy at the first control examination we noted a prolactin decrease in the IA subgroup by an average $111 \%(124.3 \pm 7.1 \mathrm{ng} / \mathrm{mL})$, which practically corresponds to the gestational norm (IB subgroup $262.4 \pm 8.9 \mathrm{ng} / \mathrm{mL})(p<0.05)$. Pregnant women with a history of endocrine infertility were characterized by a more significant decrease in the average prolactin index - by $126 \%(119.7 \pm 8.1 \mathrm{ng} /$ $\mathrm{ml}$ ) compared to the IB subgroup - $271.6 \pm 7.6 \mathrm{ng} / \mathrm{mL}(\mathrm{p}<0.05)$. Subgroup IIIB showed a $36 \%$ decrease in the average prolactin level $(127.6 \pm 8.4 \mathrm{ng} / \mathrm{ml})$ compared to the subgroup IIIB -259.2 $\pm 9.1 \mathrm{ng} / \mathrm{mL}(\mathrm{p}<0.05)$.

Repeated prolactin determination in the dynamics of treatment at 33-34 weeks of pregnancy demonstrates a stable level within the permissible physiological norm of the average indicator of this hormone in women who received the proposed complex.

The average prolactin value at 33-34 weeks of pregnancy in the IA subgroup increased in accordance with the physiological norm to $154.3 \pm 8.2 \mathrm{ng} / \mathrm{mL}$, which is $92 \%$ less compared to the IB subgroup $-297.7 \pm 10.4 \mathrm{ng} / \mathrm{mL}(\mathrm{p}<0.05)$. The average cortisol value in the subgroup IIA was $167.9 \pm 9.5 \mathrm{ng} / \mathrm{mL}$, which is $71 \%$ less than in the subgroup IIB $-287.3 \pm 9.5 \mathrm{ng} / \mathrm{mL}(p<0.05)$. At the same time the average cortisol value in the subgroup IIIB was $159.5 \pm 10.1 \mathrm{ng} / \mathrm{mL}$, which is $73 \%$ less compared to the subgroup IIIB $-277.3 \pm 9.1 \mathrm{ng} / \mathrm{mL}(\mathrm{p}<0.05)$.

The average cortisol values in subgroups IA, IIA, and IIIA approached the indicator in the control group and the physiological norm and had no significant differences $(p>0.05)$.

\section{CONCLUSION}

Advanced therapy with micronized progesterone in combination with magnesium saturation, L-arginine aspartate, folic acid, $\omega-3$ polyunsaturated fatty acids, as well as long-term psychoemotional correction is appropriate and effective compared to conventional therapy for pregnant women. This is is confirmed by a progressive $\beta$-hCG biosynthesis increase by an average of $32 \%$, progesterone by of $71 \%$, restoration of estrogen-progesterone ratio against the background of stress-associated hormones normalization (decrease of average cortisol by $47 \%$ depending on the pregnancy duration).

\begin{tabular}{|c|c|}
\hline 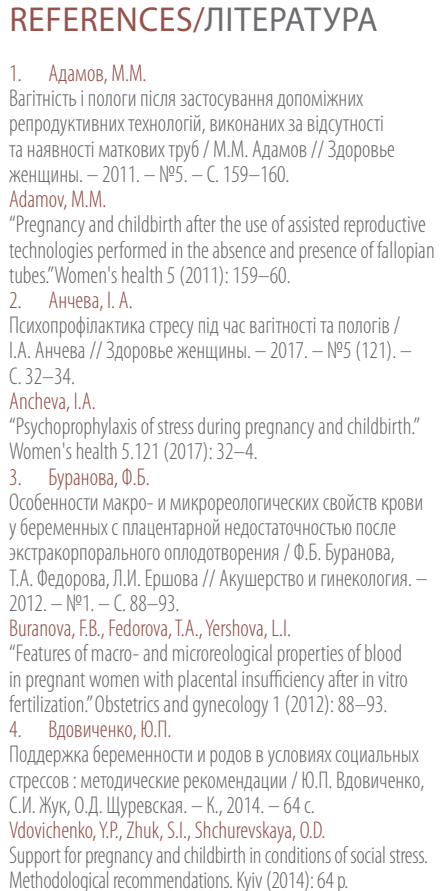 & 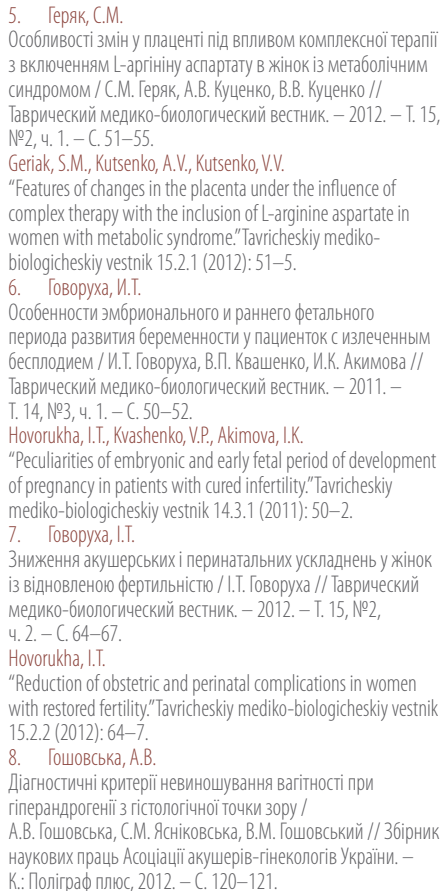 \\
\hline
\end{tabular}


Goshouska, AV Yasnikouska, SM. Goshouskyi, VM.

"Diagnostic criteria for hyperandrogenism in miscarriage from a histological point of view."In: Scientific digest of the Association of Obstetricians and Gynecologists of Ukraine. Kyiv (2012): 120-1. 9. Дахно, Ф.В.

Допоміжні репродуктивні технології лікування безпліддя:

навчальний посібник / за ред. Ф.В. Дахна, В.В. Каменського,

0.M. Юзька. - K., 2011. -338 C.

Dakhno, F.V., Kaminskiy, V.V., Yuzko, O.M., eds.

Assisted reproductive technologies for infertility treatment: a

textbook. Kyiv (2011): 338 p.

10. Демина, Т.H.

Особенности формирования маточно-(пре)плацентарного

кровотока у беременных сугрозой аборта в раннем сроке

на фоне гипопрогестеронемии / Т.Н. Демина, И.И. Воронова

// Збірник наукових праць Асоціації акушерів-гінекологів

України. - К.: Поліграф плюс, 2013. - С. 117-121.

Demina, T.N., Voronova, I.I.

"Features of the formation of utero - (pre)placental blood flow in

pregnant women with the threat of abortion in early pregnancy

against the background of hypoprogesteronemia." In: Scientific

digest of the Association of Obstetricians and Gynecologists of

Ukraine. Kyiv. Poligraf plus (2013): 117-21.

Довжикова, И.В.

Кортизол при беременности (обзор литературы)

И. В. Довжикова // Бюл. ВСНЦ СО РАМН. - 2010.-

№6, 4. I. - C. 226-229.

"Cortisol during pregnancy (review of literature)." Bull. VSNTS SO

RAMN 6.1 (2010): 226-9.

12. Жилка, H.8.

Сучасні допоміжні репродуктивні технології : методичні рекомендації / Н.Я. Жилка, В.А. Пітько, В.І. Грищенко [та ін.];

103 України. - K., 2006. -23 с.

Zhylka, N.Y., Pitko, V.A., Grishchenko, V.I., et al.; MoH of Ukraine Modern auxiliary reproductive technologies. Methodological recommendations. Kyiv (2016): 23 p

13. Корчинська, 0.0

Морфометричні показники плацент у жінок з плацентарною дисфункцією на фоні гіпергомоцистеїнемії / 0.0. Корчинська ГВ. Ігнат // Таврический медико-биологический вестник. 2012. - T. 15, №2, 4. 2. - C. 311

Korchinska, O.A. lgnat, G.V.

"Morphometric indicators of placentas in women with placental

dysfunction on the background of hyperhomocysteinemia:"

Tavricheskiy mediko-biologicheskiy vestnik 15.2.2 (2012): 311

14. Линде, В.А.

Роль аргининового дисбаланса в развитии плацентарной

недостаточности / В.А. Линде, ТН. Погорелова Н. А. Пруккер //

Акушерство и гинекология. - 2011. - №4. - С. 26-30.

linde, V.A., Pogorelova, T.N. Drucker, N.A.

"Role of arginine imbalance in the development of placental

insufficiency." Obstetrics and gynecology 4 (2011): 26-30.

15. Менжинская, И.В.

Распределение по подклассам lgG и патогенетическая

активность аутоантител к хорионическому гонадотропину

человека при нарушениях репродуктивной функции у женщи

/ И.В. Менжинская // Акушерство и гинекология. - 2011.

№3. - C. 32-37.
Menzhinskaya, I.V.

"Distribution by subclasses of Immunoglobulin $\mathrm{G}$ and pathogenetic

activity of autoantibodies to human chorionic gonadotropin in

disorders of

gynecology 3 (2011): 32-7.
16. М0зУкраїни

Наказ від 09 вересня 2013 року № 787 «Про затвердження

Інструкції про порядок застосування допоміжних

репродуктивних технологійу.

Ministry of Health of Ukraine.

Order No. 787 of September 09, 2013 "On approval of instructions

on the procedure for using assisted reproductive technologies."

17. МОЗУкраїни.

Наказ від 15.07.2011 р. № 417 «Методичні рекомендації щодо надання амбулаторної акушерсько-гінекологічної допомоги».

Ministry of Health of Ukraine.

Order No. 417 of July 15, 2011"Methodological recommendations for providing outpatient obstetric and gynecological care"

18. М0ЗУкраїни.

Наказ від 29.11.04 р. № 579 «Про затвердження Порядку

направлення жінок на лікування безплідності методами

допоміжних репродуктивних технологій за абсолютними

показаннями за бюджетні кошти».

Ministry of Health of Ukraine.

Order No. 579 of November 29, 2004"On approval of the procedure

for sending women for infertility treatment using assisted

reproductive technologies for absolute indications for budge funds."

19 Нечаева, MA.

Методика «Тип отношения к беременности»: технология

разработки, психометрические характеристики / М.А. Нечаев

М.А. Беребин // Вестник ЮурГУ. - 2011. - №11. - С. 66-76.

Nechaeva, M.A., Berebin, M.A.

"Methodology'Type of attitude to pregnancy': development

echnology psychometric characteristics" Bulletin of State

University of South Ural 11 (2011): 66-76.
20. Татарчук, Т. Ф.

есение стресс-индуцированной недостаточности лютеиновой

фазы / Т.Ф. Татарчук, Н.В. Косей // Здоровье женщины.

2016. - №3. - C. $18-22$

"Treatment of stress-induced luteal phase insufficiency"Women's

Health 3 (2016): 18-22

21. Чайка, В.К.

Основы репродуктивной медицины : практическое руководство

/ под ред. проф. В.К. Чайки. - Донецк: Лавис, 2011. - 896 с.

Chaika, V.K. ed.

Fundamentals of reproductive medicine: a practical guide. Donetsk.

Lavis (2011): $896 \mathrm{p}$.

22. Barber, D., Mounce, G.

"Women's experiences of antenayal services following IVF: a

qualitative study. Abstracts of the 29th Annual Meeting of the

European Society of Human Reproductionuction and Embriology

7-10 July 2013, London, United Kingdom." Human Reproduction 28 Suppl 1 (2013): $57-8$

23. Ferraretti, A., Goossens, V., de Mouzon, J., et al.

"Assisted reproductive technology in Europe, 2010: results

generated from European registers by ESHRE." Human Reproduction

28 Suppl 1 (2013): 38-9

24. Kalifa, E, Gliozheni, O Goldstein H.

"Massive vulvar edema in a patient with hyperstimulation ovarian

syndrome." In: Materials of 18th World Congress on Controversies in

obstetrics, gynecology \& infertility (COGI), October 24-27, 2013,

Vienna, Austria. Vienna (2013): 71-5.

25. Lowndess Stevenson, E.

Psychological stress in women who have conceived pregnancies

via in vitro fertilization."Human Reproduction 28 Suppl 1 (2013): 20-1.

\section{EFFICIENCY EVALUATION OF THE IMPROVED TREATMENT AND PREVENTION COMPLEX IN PREGNANT WOMEN AFTER ASSISTED REPRODUCTIVE TECHNOLOGIES}

V.0. Beniuk, MD, professor, head of the Obstetrics and Gynecology Department No. 3, Bogomolets National Medical University, Kyiv

L.M. Vygivska, PhD, assistant professor, Obstetrics and Gynecology Department No. 3, Bogomolets National Medical University, Kyiv

I.V. Maidannyk, PhD, assistant professor, Obstetrics and Gynecology Department No. 3, Bogomolets National Medical University, Kyiv

T.V. Kovaliuk, PhD, assistant professor, Obstetrics and Gynecology Department №. 3, Bogomolets National Medical University, Kyiv

0.0. Chorna, PhD, assistant professor, Obstetrics and Gynecology Department No. 2, Bogomolets National Medical University, Kyi

S.V. Beniuk PhD assistant professor, Obstetrics and Gynecology Department No. 3 , Bogomolets National Medical University Kyir

I.A. Usevych, PhD, assistant professor, Obstetrics and Gynecology Department No. 3, Bogomolets National Medical University, Kyiv

Study objective: to determine the role and effectiveness of the proposed therapeutic and preventive complex and psychoemotional correction of hormonal disorders in the pregnancy dynamics after assisted reproductive technologies (ART) to improve the antenatal observation and prevention of obstetric and perinatal complications.

Materials and methods. The study included 299 pregnant women: the main group included 249 women whose pregnancy occurred as an ART result: the control group included 50 pregnant women with spontaneous pregnancy. Therapeutic and prophylactic complex for pregnant women after ART included: micronized progesterone, magnesium oxide, folic acid, L-arginine aspartate, $\omega 3$-polyunsaturated fatty acids and long-term psychological correction on the eve of the ART program, at 8 -10, $16-18$ and 28 - 30 weeks of pregnancy. Results. There was a significant increase in the $\beta$-chorionic gonadotropin ( $\beta$-h(G) level in women of the study groups in the first trimester of pregnancy against the background of the proposed treatment.

Mean $\beta-H C G$ value at $7-8$ weeks of gestation in the subgroup IA exceeded the subgroup IB by $37 \%(p<0.05)$, in subgroup IIA it exceeded the subgroup IIB by $33 \%$ ( $p<0.05)$. The mean $\beta$-hCG value in subgroups IIIA and IIIB did not have a significant difference in the dynamics of the first trimester compared with the control group and among themselves $(p>0.05)$.

Mean progesterone value at $7-8$ weeks of gestation in subgroup IA increased by $38 \%$ in comparison with pregnant women who received the conventional treatment complex ( $p<0.05$ ), in subgroup $\| A$ it was $73 \%$ higher than in subgroup IIB ( $p<0.05$ ). There was $n 0$ significant difference in the progesterone level in subgroups IIIA and IIIB in the dynamics of the first trimester.

The average cortisol value at $23-24$ weeks of pregnancy in subgroup IA decreased by $42 \%$ ( $p<0.05$ ), in pregnant women with endocrine infertility against the background of the proposed treatment complex it was $62 \%$ less than in subgroup IIB ( $p<0.05$ ). The average cortisol level in women with a male factor of infertility was $63 \%$ lower than in subgroup IIIB against the background of the proposed complex $(p<0.05)$.

Conclusion. Advanced therapy with micronized progesterone in combination with magnesium saturation, L-arginine aspartate, folic acid, $\omega$-3 polyunsaturated fatty acids, as well as long-term psychoemotional correction is appropriate and effective compared to conventional therapy for pregnant women.

Keywords: assisted reproductive technologies, $\beta$-chorionic gonadotropin, progesterone, cortisol, prolactin, stress-related hormones.

ОЦІККА ЕФЕКТИВНОСТІ ВДОСКОНАЛЕНОГО ЛІКУВАЛЬНО-ПРОФІЛАКТИЧНОГО КОМПЛЕКСУ У ВАГІТНИХ ПІСЛЯ ЗАСТОСУВАННЯ ДОПОМІЖНИХ РЕПРОДУКТИВНИХ ТЕХНОЛОГІЙ

В.О. Бенюк, д. мед. н., професор, зав. кафедри акушерства і гінекології №3, Нму ім. 0.0. Богомольця, м. Київ Л.М. Вигівська, к. мед. Н., доцент кафедри акушерства г гінекології № 3, НМУ імені 0.0. Богомольця, м. Київ

І.В. Майданник, к. мед. Н., доцент кафедри акушерства і гінекологї № 3, НМУ імені 0.0. Богомольця, м. Київ

Т.В. Ковалюк, К. мел. н. доцент кафедри ақушерства і гінекології№ 3 . НМУ імені 0.0. Богомольця, м. Київ

0.0 Чорна, к. .ед. .

С.В. Бенюк, К. мед. н., доцент кафедри акушерства і гінекології № 3, НмУ імені 0.0. Богомольця, м. Київ

І.А. Усевич, к. мед. Н., доцент кафедри акушерства і гінекології № 3, НмУ імені 0.0. Богомольця, м. Київ

Мета дослідження. Визначити ефективність запропонованого лікувально-профілактичного комплексу та психоемоційної корекції гормональних порушень в динаміці вагітності після допоміжних репродуктивних технологій (ДРТ) для вдосконалення тактики антенатального спостереження та профілактики акушерських і перинатальних ускладнень.

Матеріали та методи. У дослідження увійшли 299 вагітних: до основної групи - 249 жінок, вагітність яких настала в результаті застосування ДРТ, до контрольної групи - 50 вагітних зі спонтанним настанням вагітності. Комплекс лікувальнопрофілактичних заходів для вагітних після ДРТ включав: мікронізований прогестерон, магнію оксид легкий, фолієву кислоту, L-аргініну аспартат, ш3-поліненасичені жирні кислоти і тривалу психологічну корекцію - напередодні програми ДРТ, на 8-10, 16-18і 28-30 тижнях вагітності.

Результати. На фоні запронованого лікування спостерігався достовірний приріст рівня ß-хоріонічного гонадотропіну ( $\beta$-ХГ) ужінокдосліджуваних груп в І триместрі вагітності. У $7-8$ тижнів гестації середнє значення $\beta$-ХГ жінокпідгрупи ІА перевищувало показник

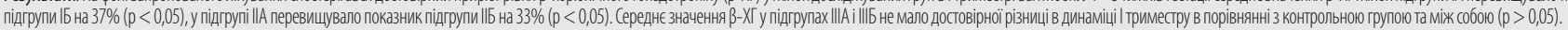
у 7-8 тижнів гестації середне значення прогестерону в підгрупі ІА зростало в середньому на 38\% у порівнянні з вагітними, які отримували загальноприйнятий лікувальний комплекс (р <0,05), у підгрупі ІІА на 73\% перевищувало показники вагітних підгрупи ІІБ (р <0,05). Достовірної різниці в рівні прогестерону в підгрупах ІІА і ІІІБ в динаміці І триместру не відзначено.

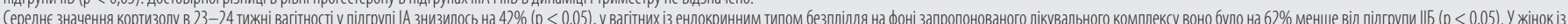
чоловічим фактором безпліддя середній рівень кортизолу на фоні запропонованого комплексу був на 63\% меншим порівняно $з$ підгрупою ІІІБ $(p<0,05)$.

Висновок. Призначення вагітним удосконаленої терапії мікронізованим прогестероном у поєднанні 3 магнієм, L-аргініну аспартатом, фолієвою кислотою, ш3-поліненасиченими жирними кислотами, а також тривала психоемоційна корекція є доцільними й ефективними порівняно із загальноприйнятими методами лікування.

Ключові слова: допоміжні репродуктивні технології, $\beta$-хоріонічний гонадотропін, прогестерон, кортизол, пролактин, стрес-асоційовані гормони.

ОЦЕНКА ЭФФЕКТИВНОСТИ УСОВЕРШЕНСТВОВАННОГО ЛЕЧЕБНО-ПРОФИЛАКТИЧЕСКОГО КОМПЛЕКСА У БЕРЕМЕННЫХ ПОСЛЕ ПРИМЕНЕНИЯ ВСПОМОГАТЕЛЬНЫХ РЕПРОДУКТИВНЫХ ТЕХНОЛОГИЙ

В.А. Бенюк, д. мед. Н., професор, зав. кафедрой акушерства и гинекологии №3, НмУ им. А.А. Богомольца, г. Киев

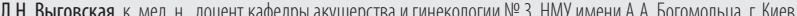

И.В. Майданник, к. мел. н., доцент кафедры акушерства и гинекологии № 3, НМУ имени А.А. Богомольца, г. Киев

Т.В. Ковалюк, к. мед. Н., доцент кафедры акушерства и гинекологии № 3, нМУ имени А.А. Богомольца, г. Киев

Е.А. Черная, к. мед. Н., доцент кафедры акушерства и гинекологии № 2. НМУ имени А.А. Богомольца, г. Киев

С.В. Бенюк, К. мед. н., доцент кафедры акушерства и гинекологии № 3, НМУ имени А.А. Богомольца, г. Киев

И.А. Усевич, к. мед. Н., доцент кафедры акушерства и гинекологии № 3, НмУ имени А.А. Богомольца, г. Киев

Цель исследования: определить эффективность предложенного лечебно-профилактического комплекса и психоэмоциональной коррекции гормональных нарушений в динамике беременности после вспомогательных репродуктивных технологий (ВРT) для совершенствования тактики антенатального наблюдения и профилактики акушерскихи перинатальных осложнений.

Материалы и методы. В исследование вошли 299 беременных женщин: в основную группу - 249 женщин, беременность которых наступила в результате применения ВРТ, в контрольную группу - 50 беременных со спонтанно наступившей беременностью. Комплекс лечебно-профилактических мероприятий для беременных после ВРТ включал: микронизированный прогестерон, магния оксид, фолиевую кислоту, L-аргинина аспартат, ш3-полиненасыщенные жирные кислоты и длительную психологическую коррекцию - накануне программы ВРТ, на 8-10, 16-18 и $28-30$ неделях беременности.

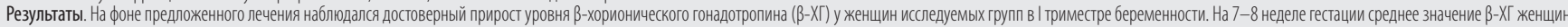
подгруппы IA превышало показатель подгруппы IБ на 37\% (p <0,05), а в подгруппе ІІА превышало показатель подгруппы ІІБ на 33\% ( $<$ < 0,05). Среднее значение $\beta$-ХГ в подгруппах ІІІА и ІІІБ не имело достоверной разницы в динамике первого триместра по сравнению с контрольной группой и между собой $(p>0,05)$

B 7-8 недель гестации среднее значение прогестерона в подгруппе ІА выросло в среднем на 38\% в сравнении с беременными, получавшими общепринятый лечебный комплекс (p <0,05), в подгруппе ІІА на 73\% превышало показатели беременных подгруппы IIБ ( $(<0,05)$. Достоверной разницы в уровне прогестерона в подгруппах ІІА и ІІІБ в динамике первого триместра не отмечено.

(реднее значение кортизола в 23-24 недели беременности в подгруппе ІА снизилось на 42\% ( $><0,05)$, у беременных с эндокринным типом бесплодия на фоне предложенного лечебного комплекса оно было на 62\% меньше, чем в подгруппе ІІБ $(p<0,05)$. У женщин с мужским фактором бесплодия средний уровень кортизола на фоне предложенного комплекса был на 63\% меньше по сравнению с подгруппой III ( $(p<0,05)$.

Вывод. Назначение беременным усовершенствованной терапии микронизированным прогестероном в сочетании с магнием, L-аргинина аспартатом, фолиевой кислотой, ш3-полиненасыщенными жирными кислотами, а также длительная

психоэмоциональная коррекция являются целесообразными и эффективными по сравнению с общепринятыми методами лечения.

Ключевые слова: вспомогательные репродуктивные технологии, В-хорионический гонадотропин, прогестерон, кортизол, пролактин, стресс-ассоциированные гормоны. 